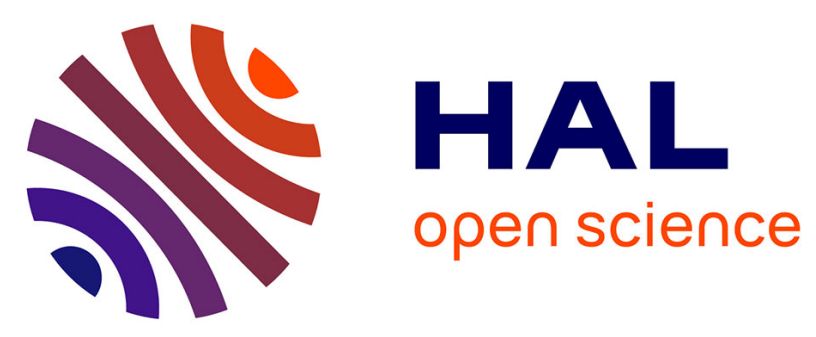

\title{
Prospective associations between energy balance-related behaviors at 2 years of age and subsequent adiposity: the EDEN mother-child cohort
}

Cécilia Saldanha-Gomes, Barbara Heude, M-A Charles, Blandine de Lauzon-Guillain, Jérémie Botton, Sophie Carles, Anne Forhan, Patricia Dargent-Molina, Sandrine Lioret, Eden Mother-Child Cohort Study Group

\section{To cite this version:}

Cécilia Saldanha-Gomes, Barbara Heude, M-A Charles, Blandine de Lauzon-Guillain, Jérémie Botton, et al.. Prospective associations between energy balance-related behaviors at 2 years of age and subsequent adiposity: the EDEN mother-child cohort. International Journal of Obesity, 2017, 41 (1), pp.38-45. 10.1038/ijo.2016.138 . hal-02898156

\section{HAL Id: hal-02898156 \\ https://hal.inrae.fr/hal-02898156}

Submitted on 13 Jul 2020

HAL is a multi-disciplinary open access archive for the deposit and dissemination of scientific research documents, whether they are published or not. The documents may come from teaching and research institutions in France or abroad, or from public or private research centers.
L'archive ouverte pluridisciplinaire HAL, est destinée au dépôt et à la diffusion de documents scientifiques de niveau recherche, publiés ou non, émanant des établissements d'enseignement et de recherche français ou étrangers, des laboratoires publics ou privés. 
Prospective associations between energy balance-related behaviors at 2 years of age and subsequent adiposity: the EDEN mother-child cohort

Cécilia Saldanha-Gomes, Barbara Heude, Marie-Aline Charles, Blandine de Lauzon-Guillain, Jérémie Botton, Sophie Carles, Anne Forhan, Patricia Dargent-Molina, Sandrine Lioret; on behalf of the EDEN mother-child cohort study group ${ }^{1}$.

\section{Affiliations:}

INSERM, UMR1153 Epidemiology and Biostatistics Sorbonne Paris Cité Center, Early

ORigin of the Child's Health and Development Team (ORCHAD), Paris, F-75014 France. (CSG, BH, MAC, BLG, JB, SC, AF, PDM, SL)

Paris-Sud University, Faculty of medicine. Kremlin-Bicêtre, France. (CSG, SC)

Paris Descartes University, Paris, France. (BH, MAC, BLG, AF, PDM, SL).

Paris-Sud University, Faculty of Pharmacy, Châtenay-Malabry, France. (JB).

${ }^{1}$ Members of the EDEN Mother-Child Cohort Study Group: I. Annesi-Maesano, J.Y. Bernard, J. Botton, M.A. Charles, P. Dargent-Molina, B. de Lauzon-Guillain, P. Ducimetière, M. de Agostini, B. Foliguet, A. Forhan, X. Fritel, A. Germa, V. Goua, R. Hankard, B. Heude, M. Kaminski, B. Larroque†, N. Lelong, J. Lepeule, G. Magnin, L. Marchand, C. Nabet, F Pierre, R. Slama, M.J. Saurel-Cubizolles, M. Schweitzer, O. Thiebaugeorges.

\section{Conflict of interest}

None of the authors had a conflict of interest.

Corresponding Author (and requests for reprints): S Lioret, INSERM, UMR1153

Epidemiology and Biostatistics Sorbonne Paris Cité Center (CRESS), Early ORigin of the Child's Health And Development Team (ORCHAD), 16, avenue Paul Vaillant Couturier, 
94807 Villejuif Cedex France. sandrine.lioret@inserm.fr. Tel 3314559 51 78, Fax: 33147 269454.

Funding: We acknowledge all funding sources for the EDEN study: Foundation for Medical Research (FRM), National Agency for Research (ANR), National Institute for Research in Public Health (IRESP: TGIR cohorte santé 2008 program), French Ministry of Health (DGS), French Ministry of Research, INSERM Bone and Joint Diseases National Research (PRO-A) and Human Nutrition National Research Programs, Paris-Sud University, Nestlé, French National Institute for Population Health Surveillance (InVS), French National Institute for Health Education (INPES), the European Union FP7 programmes (FP7/2007-2013, HELIX, ESCAPE, ENRIECO, Medall projects), Diabetes National Research Program (through a collaboration with the French Association of Diabetic Patients (AFD)), French Agency for Environmental Health Safety (now ANSES), Mutuelle Générale de 1'Education Nationale (a complementary health insurance fund) (MGEN), French national agency for food security, French-language association for the study of diabetes and metabolism (ALFEDIAM). The funders had no influence of any kind on the analyses or the interpretation of the results.

Short running head: Early obesogenic energy balance-related behaviors

\footnotetext{
Abbreviations: bioelectrical impedance analysis (BIA); Body mass index (BMI); Energy balance-related behaviors (EBRBs); Food frequency questionnaire (FFQ); Percentage of body fat (\%BF); Principal component analysis (PCA); Socio-economic position (SEP).
} 


\section{$1 \quad$ Abstract}

2 Background/Objectives Sedentary behavior, physical activity and dietary behavior are formed early during childhood and tend to remain relatively stable into later life. No longitudinal studies have assessed the independent influence of these three energy balance-related behaviors during toddlerhood on later adiposity. We aimed to analyze the associations between screen time, outdoor play time, and dietary patterns at age 2 years and child adiposity at age 5 , in boys and girls separately.

Subjects/Methods This study included 883 children from the French EDEN mother-child cohort. Screen time, outdoor play time and dietary intakes were reported by parents in questionnaires when the child was aged 2. Two dietary patterns, labelled "Guidelines" and "Processed, fast-foods", were identified in a previous study. Percentage of body fat (\%BF) based on bioelectrical impedance analysis and body mass index were measured at age 5 .

Results In boys, screen time at age 2 was positively associated with $\%$ BF at age $5(\beta=0.51(95 \%$ confidence interval (CI): 0.02, 1.01) for those boys with $\geq 60 \mathrm{~min} /$ day of screen time vs. those with $\leq 15 \mathrm{~min} /$ day, $P$ for trend 0.045$)$. In girls, outdoor play was inversely associated with $\% \mathrm{BF}(\beta=-0.93$ (95\%CI: $-1.58,-0.28)$ for those in the highest tertile of outdoor play time vs. those in the lowest tertile, $P=0.002)$. Overall, at age 2 , dietary patterns were associated with both screen time and outdoor play time, but no significant and independent association was observed between dietary patterns and later adiposity.

Conclusion This study shows longitudinal and gender differentiated relations between both screen time and outdoor play time in toddlerhood and later adiposity, while evidence for a relation between dietary patterns and subsequent fat development was less conclusive. Early childhood - by age 2 should be targeted as a critical time for promoting healthy energy balance-related behaviors. 


\section{6 INTRODUCTION}

27 Childhood overweight and obesity have reached epidemic proportions worldwide. ${ }^{1}$ In 2010 , the estimated prevalence among preschool children was as high as $11.7 \%$ in developed countries and $6.1 \%$ in developing countries. ${ }^{2}$ This epidemic has reached the whole pediatric population, with secular trends towards higher fat mass in both obese and non-obese children. Beyond any predisposition due to genetic susceptibility or programming of later adiposity by the intrauterine environment, the rapid increase in adiposity in recent decades in young children may also indicate that obesogenic energy balance-related behaviors (EBRBs), namely high levels of sedentary behaviors, low levels of physical activity and unhealthy dietary behaviors, come into play at an early age. ${ }^{34}$

Early childhood ( $<5$ years) is critical for the setting of EBRBs for a number of reasons. Early exposure to active play stimulates motor skills, which predict later physical activity. ${ }^{5}$ Early food experiences influence the development of taste and food preferences, which in turn affect subsequent eating habits. ${ }^{6-8}$ Furthermore, there is some evidence that sedentary behaviors, physical activity and dietary intakes track (the concept of tracking relates to the stability, or relative ranking within a cohort, of behaviors over time) from early childhood into later childhood, adolescence and even adulthood..$^{9-13}$ The early establishment of obesogenic EBRBs, which are maintained once habits are formed, is therefore hypothesized to lead to a cumulative increase of positive energy balance over the life course, favoring the development of body fat. ${ }^{4}$ Hence, identifying the specific early behaviors that are most predictive of later body fat development, especially those that are modifiable, is a necessary step for developing effective interventions and public health policies aimed at reducing childhood overweight and obesity.

Accumulating evidence from longitudinal studies in preschoolers (roughly aged 3-5 years at baseline) indicates that sedentary behavior - mainly television viewing - is deleterious and physical activity protective for later adiposity. ${ }^{414}$ Inconsistent evidence characterizes the prospective 
relations between early dietary behaviors and overweight. ${ }^{13-15}$ There is however a dearth of research examining these longitudinal associations among children younger than $3,{ }^{13} 16$ despite growing evidence that toddlers are already engaging in high levels of screen time ${ }^{17}$ and that suboptimal dietary patterns are already established by age $2 .{ }^{12} 18$ Moreover, despite a careful search, we have been unable to find any longitudinal studies among toddlers that have taken the three EBRBs into account simultaneously, nor have we found any that have studied boys and girls separately, although both body composition ${ }^{19}$ and physical activity ${ }^{2021}$ differ between preschool boys and girls.

We aimed to analyze the independent associations between screen time, outdoor play time, and dietary patterns at age 2 and child adiposity at age 5, assessed by comprehensive and specific measurements, including bioelectrical impedance analysis. We hypothesized that outdoor play time and healthy dietary patterns would be protective against the development of adiposity, while screen time and non-healthy dietary patterns would not be. We assumed that the effects might be modified by gender and therefore conducted the analysis separately in boys and girls.

\section{SUBJECTS AND METHODS}

\section{Subjects}

The EDEN mother-child study is a prospective cohort designed to assess pre- and postnatal determinants of child health and development; it has been described in detail elsewhere. ${ }^{22}$ In brief, between 2003 and 2006, 2002 pregnant women (<24-weeks' gestation) aged 18-44 years were recruited in two university hospital maternity clinics, in Nancy and Poitiers, France. Exclusion criteria were multiple pregnancies, diabetes history, French illiteracy, and plans to move out of the region within the next three years. Approval for the study was obtained from the relevant ethics committee (ID 0270 of 12 December 2012) and the French Data Protection Authority (CNIL, ID 902267 of 12 December 2012). Written consents were obtained from each participant. 
There were 1903 live born children; 1266 sets of parents returned the questionnaire with complete or imputed data for the child EBRBs at age 2; the participants selected for this study are the 883 for whom data were available for both anthropometric and bioelectrical impedance analysis (BIA) measurements at age 5 (Figure 1). The current sample thus comprised 473 boys and 410 girls with both behavioral and adiposity measurements.

\section{Adiposity measurements at age 5}

Anthropometric and bioelectrical impedance data were collected during the clinical examination that took place at the Nancy and Poitiers university hospitals when the child was 5 (mean 5.65 years, SD 0.16). Measurements were performed by trained investigators, using standard procedures. Anthropometric measurements. Height and weight were measured twice, then averaged. The children's heights were measured to the nearest $0.1 \mathrm{~cm}$ with wall-mounted stadiometers (Model 208, SECA, Hamburg, Germany) as they stood barefoot, and their weights to the nearest $0.2 \mathrm{~kg}$ with an electronic scale (Model 888, SECA, Hamburg, Germany), while they wore light underwear. Body mass index (BMI) was calculated as weight $(\mathrm{kg}) / \mathrm{height}^{2}\left(\mathrm{~m}^{2}\right)$. Skinfold thickness was taken three times, then averaged, to the nearest $0.2 \mathrm{~mm}$ at the left triceps and subscapular sites, with a Holtain skinfold caliper (Chasmors Ltd, London, UK).

Bioelectrical impedance analysis (BIA) measurements. All children underwent BIA twice (and the two measurements were averaged), with a single-frequency impedance analyzer (Model BIA 101, Akern-RJL, Italy) after 5 minutes of rest and with an empty bladder.

Percentage of body fat. The estimated percentage of body fat (\%BF) was based on the anthropometric and BIA measures and used three different equations: from Houtkooper et al., ${ }^{23}$ Slaughter et al. ${ }^{24}$ and Goran et al. ${ }^{25}$ The latter, which takes body resistance and all anthropometric measures listed above (height, weight, and skinfold thickness) into account, was developed among 
white children aged 4-9 years. Because it was considered the most suitable for our study population, it was prioritized in the analysis.

\section{Energy balance-related behaviors at age 2}

Sedentary behavior and physical activity. Postal questionnaires were sent to parents and completed, primarily by mothers, when the children were aged 2 (mean 2.03 years, SD 0.09). Sedentary behavior was assessed from the responses to three questions regarding the time (in $\mathrm{min} /$ day) that the child spent watching television or playing video or computer games, on a typical weekday (excluding Wednesday), Wednesday (which was a day off school at the time of the study), and weekend days; there was one question for each type of day. Similarly, physical activity was assessed from three questions about the time the child usually spent playing outdoors (e.g., in a backyard, a park, a playground) for each type of day. An average daily time was calculated and weighted for both types of activity. Sedentary screen time was split into three categories, i.e., $\leq 15$ $\mathrm{min} /$ day, $>15 \mathrm{~min} /$ day to $<1 \mathrm{~h} /$ day, and $\geq 1 \mathrm{~h} /$ day, which corresponded to tertiles in our population. Given the children's age and the period of data collection (2005-2008), we can reasonably think that television (and DVDs) accounted for most of the screen time in our study. ${ }^{26}$ There is evidence of seasonal variations in physical activity, especially for the time children spend playing outdoors. ${ }^{27}$ Hence, the daily time spent playing outdoors was categorized into season-specific tertiles (low, intermediate, and high). Imputations were done for 187 children when one or two items of the three (i.e., weekday, Wednesday, weekend day) were missing for a given activity, based on the values available for any other day.

Dietary patterns. Children dietary intake at age 2 was collected with a food frequency questionnaire (FFQ) included in the postal questionnaire and described in detail elsewhere. ${ }^{12}$ In brief, the food classification was established based on similarities in food type and context of consumption and was designed to be able to describe the patterns of the child's diet. The FFQ included 26 food 
groups along with seven possible responses, ranging from "Never" to "Several times per day"; all were converted into weekly frequencies. A previous analysis of these data ${ }^{12}$ using principal component analysis (PCA), identified two dietary patterns, which accounted for $19.8 \%$ of the explained variance. The first pattern, labelled "Processed, fast-food", was positively correlated with intake of French fries, processed meat, carbonated soft drinks, crisps, biscuits, pizzas, fruit juices, dairy puddings and ice cream, legumes, and bread (by descending order of factor loadings) and inversely correlated with the intake of cooked vegetables. The second pattern, labelled "Guidelines", was mainly characterized by high consumption frequency of cooked vegetables, rice, fruits, raw vegetables, low fat fish, potatoes, ham, compotes, meat, and bread. Scores for each pattern were calculated at the individual level by summing the observed standardized frequencies of consumption per food group, weighted according to the PCA loadings.

\section{Covariates}

Baseline BMI. Using the Jenss-Bayley nonlinear model and measurements collected from the child's health care booklet (birth to 5 years) and at the clinical examinations undertaken at the university clinics at ages 1,3 , and 5, we fitted individual weight and height growth trajectories. ${ }^{28}$

The resulting equation allowed us to predict both weight and height and therefore BMI at age 2 .

Socio-economic position (SEP). Since SEP is a recognized covariate of diet in early childhood, ${ }^{18} 29$ the analysis adjusted for maternal education (the highest diploma obtained: less than high-school, high school diploma, 2-year university degree and $\geq 3$ year university degree) and monthly household income (in $€$ ) at inclusion (categorized as $\leq 1500,1501$ to 2300,2301 to 3000,3001 to $3800,>3800)$.

\section{Statistical analysis}


149 The study population was compared to the EDEN population not selected for this study (that is, the 150 initially included families with live born children for whom any of behavioral variables at age 2 or

151 adiposity measurements at age 5 were not available) for infant birth characteristics, parental

152 demographic characteristics and SEP. Within the study population, boys and girls were compared

153 for EBRBs, adiposity outcomes, and covariates. Chi-square tests were used for categorical variables

154 and Student t-tests for continuous variables. The relations between the EBRBs at age 2 were also

155 assessed, adjusting for SEP and study center, with multivariable linear and ordinal logistic

156 regression analyses.

157 Multivariable linear regression analysis was used to assess the association between EBRBs at age 2

158 and adiposity at age 5. For each of the four outcomes (i.e., BMI and \%BF with each of the three

159 equations described above), the analysis was conducted in two steps. First, screen time, outdoor

160 play time, and dietary patterns were each included in separate models. Then the three EBRBs were

161 included simultaneously along with the SEP variables in a single model, referred as the fully-

162 adjusted model. All models were run for boys and girls separately, and adjusted for center (Poitiers

163 or Nancy), baseline BMI, and exact age at the 5-year clinical examination. Finally, sensitivity

164 analyses were carried out for the sample excluding children with imputed data (complete case

165 sample, $\mathrm{n}=756)$.

166 SAS 9.3 was used for the statistical analyses, and the level of significance set at $\mathrm{P}<0.05$.

168 RESULTS

169 Characteristics of the study population

170 Table 1 summarizes the characteristics of boys and girls in the study sample. At age 2, the boys

171 spent more time playing outdoors and had a slightly lower mean BMI than girls. There was no

172 significant difference between genders for either dietary pattern scores or screen time. Overall,

$17312.2 \%$ of the 2-year-old children spent no time on screen activities, $54.7 \%$ less than $1 \mathrm{~h} /$ day, and 
$33.1 \% 1 \mathrm{~h}$ /day or more. At age 5, \% BF and prevalence of overweight (including obesity) were both significantly lower among boys than girls.

Compared to non-selected children, children selected for the current study were less likely to have been born to a young mother (28.9 years vs. 30.2, $P<10^{-4}$ ), to have a mother with a lower education level ( $42 \%$ with education $<$ high school diploma vs. $19 \%, P<10^{-4}$ ), and to live in a low-income household ( $22.2 \%$ vs. $10.8 \%$ with household monthly income $\left.\leq 1500 €, P<10^{-4}\right)$. However, there was no significant difference in birth weight between the two samples.

\section{Interrelations between energy balance-related behaviors at age 2}

Associations between EBRBs at age 2 are presented by gender in Table 2. Among boys, higher scores for the "Processed, fast-foods" dietary pattern were positively associated with screen time. Among girls, "Guidelines" dietary pattern scores and, to a lesser extent, "Processed, fast-food" dietary pattern scores were positively associated with outdoor play time (upper tertile). There was no significant association in either gender between time spent at outdoor play and in front of a screen (results not shown).

\section{Independent associations between screen time, outdoor play time, and dietary patterns at age}

\section{2 and child adiposity at age 5}

In boys, screen time at age 2 was the only EBRB that was significantly and positively associated with $\% \mathrm{BF}$ at age 5 in the separate models (Table 3). This association remained significant and the coefficient estimates barely changed after adjustment for the other two EBRBs and for SEP. The regression coefficient estimates suggest a graded dose-response relation (adjusted linear trend $\beta$ $0.42, P=0.045)$. In girls, both the time spent playing outdoors and the score on the "guideline" dietary pattern at age 2 were significantly and negatively associated with $\% \mathrm{BF}$ at age 5 in the separate models. The association with outdoor play remained significant and the coefficient 
199 estimates barely changed in the fully adjusted model, while the association with the "Guideline" 200 dietary pattern was no longer significant. The regression coefficient estimates for outdoor play 201 suggested that the effect was driven by the upper tertile of the variable. Similar results were found 202 with the other two estimates of \%BF (i.e., based on Houtkooper's and Slaughter's equations)

203 (Supplementary Table 1). No EBRB was significantly and independently associated with BMI at 204 age 5 in either gender. Sensitivity analyses for the sample excluding children with imputed data 205 (complete case sample) produced consistent results (Supplemental Table 2).

\section{DISCUSSION}

208 This study, which highlights the precocity of the onset of behavioral risk factors for obesity, is to 209 our knowledge the first to find that the amounts of time spent on screen and in outdoor play during 210 toddlerhood are each prospectively and independently associated with later adiposity, regardless of 211 diet, SEP, and baseline BMI.

Our results confirm previous findings in preschoolers suggesting that early exposure to screens mainly measured as television viewing - is obesogenic. ${ }^{1430}$ They further show that this effect is apparent at an age as early as 2 in boys. The literature suggests several underlying mechanisms that may explain this association, including reduced resting metabolic rate ${ }^{31}$ displacement of more active pursuits, ${ }^{32}$ exposure to advertising of junk food and fast food leading to increased children's requests for those particular foods and products, and increased snacking while watching television or movies. ${ }^{33}{ }^{34}$ Consistent with observations in older children, ${ }^{35}{ }^{36}$ we found a positive association between screen time and "Processed and fast-foods" dietary pattern scores at age 2, but only in boys. This may help to explain why the positive association between screen time and later adiposity was significant only in boys, even though it was unaltered by adjustment for dietary patterns.

223 Finally, screen time has been inversely associated with sleep time,${ }^{37}$ and short sleep duration has 
been longitudinally associated with excess weight gain in early childhood. ${ }^{38}{ }^{39}$ Screen time was not associated with parent-reported sleep time at 2 years in our population (not shown). A previous cross-sectional analysis of EDEN data at 3 years did however suggest that - again for boys only short sleep duration was positively associated with both screen time and BMI. ${ }^{40}$ Current guidelines recommend to avoid exposure to screens before age 2 and to limit screen time to less than $1 \mathrm{~h}$ or $2 \mathrm{~h}$ daily between age 2 and $5 .{ }^{41-44}$ In our sample of 2-year olds, only $12.2 \%$ had no screen activities at all, while about a third had an hour or more daily. The graded dose-response shape of the association with adiposity in our results, added to the growing evidence that increased screen time in early years is associated with unfavorable scores on measures of psychological health and cognitive development, ${ }^{3045}$ is a further reason that parents should be informed about the deleterious health effects of early screen exposure.

Our findings also provide unique insights into the protective role of outdoor play in toddlerhood for later adiposity. This is consistent with the review by te Velde et al. ${ }^{14}$ that showed strong evidence for an inverse longitudinal association between objectively-measured total physical activity at preschool age and later overweight. As these authors noted, however, these findings did not allow them to identify the specific components of physical activity that drove the association. Play time spent outdoors has been positively related to total physical activity in preschoolers, ${ }^{21}$ and we can reasonably hypothesize that this is also true at age 2 , since the physical activity of children younger than 5 is essentially unstructured, and might be described more appropriately as "active free play". ${ }^{20}$ Furthermore, preschoolers are generally more physically active outdoors than indoors. ${ }^{46}$ Hence, it has been suggested that outdoor play is a major contributor of physical activity in young children. ${ }^{47}$ Toddlers who engage in more outdoor play are thus likely to expend more energy, which leads to both a healthier energy balance and stimulated motor skills. ${ }^{5}$ Of note, the negative association between outdoor play and adiposity was present only in girls. Outdoor play time may be an even 
249 better indicator of total physical activity for girls than for boys, since girls are overall less active 250 than boys and may spend more of their indoor play time in quiet play (e.g., drawing, tinkering, 251 looking into books, which are considered as productive sedentary behaviors ${ }^{26}$ ) than boys do.

252 Noteworthy, outdoor play in young children is under parental control, and there is some evidence to 253 suggest that children's physical activity is strongly associated with parental activity and 254 encouragement, especially in girls. ${ }^{48}$ Moreover, only the upper tertile of outdoor play was 255 negatively associated with later adiposity, and girls in that highest tertile also had higher scores on 256 the "Guidelines" dietary pattern. Hence, taking toddlers outdoors to stimulate their motor skills and 257 provide them with an opportunity for active play may also reflect healthier family lifestyles and 258 attitudes, especially for girls. ${ }^{48}$ Current physical activity guidelines ${ }^{49-51}$ recommend that children 259 aged 1-5 years should be physically active every day for at least a total of 3 hours, at any intensity, 260 spread throughout the day. In our sample of 2-year old French children, the upper tertile of outdoor 261 play corresponds to a median play time around 2 to 4 hours, depending on the season. Although 262 parents have traditionally assumed that young children were spontaneously and sufficiently 263 physically active, growing evidence suggests that this is not necessarily the case and that large inter264 individual variability exists. ${ }^{20} 52$ Young girls are even less active than young boys, ${ }^{2021}$ and our 265 results suggest that encouraging outdoor play may be a particularly effective way to promote 266 physical activity in young girls.

We found no strong evidence that dietary patterns at toddler ages are independent predictors of subsequent body fat at 5 years, consistent with previous studies in children 0-5 years, ${ }^{14} 1838$ but not all. ${ }^{13}$ The current lack of consensus on the influence of diet on overweight is due in part to methodological issues. Various measures have been used to define dietary intake; some studies have focused on specific nutrients or foods, while others have addressed the diet as a whole, through dietary patterns or eating behaviors. Residual confounding may also be important where analyses 
274 have not taken major covariates such as physical activity and sedentary behavior into account.

275 Finally, most existing studies linking dietary intakes and child obesity are limited by their cross276 sectional designs. Nevertheless, given that dietary patterns emerge early in life, tend to track into 277 the preschool years and beyond, ${ }^{9} 101213$ and that we found they co-varied with other EBRBs, it is 278 possible that the cumulative effect of dietary patterns on adiposity will become more visible at older 279 ages, when most children enter formal schooling and levels of physical activity tend to decrease, ${ }^{53}$ 280 as suggested by results from both the Avon Longitudinal Study of Parents and Children ${ }^{3854}$ and the 281 Southampton Women's Survey. ${ }^{13}$

A novel aspect and main strength of our study was the assessment of these associations from toddlerhood, prospectively and considering both sides of the energy equation (i.e., intake and expenditure) as well as the effect modification by gender. The comprehensive and objective measurements of adiposity, together with the consistency of these associations across different measurements of fat mass and different samples (study sample with imputed data $v s$. complete-case sample), are additional strengths of this work. Overall, our findings also show the relevance of using specific measures of body fat, because none of the associations observed was significant with BMI, which cannot distinguish between fat and fat-free mass. The sole reliance on parental report of behaviors is however a limitation in our analyses. These measurements are subject to social desirability bias and are relatively imprecise compared to objective measurements (e.g., by accelerometry), which may have attenuated the associations under study. We acknowledge that the estimation of food intake would have been more precise with a quantitative FFQ. Nevertheless, research shows that frequency of consumption is actually the major determinant of intake, while the inclusion of portion or serving size in FFQs adds limited information about variance in food intake. ${ }^{55}$ Therefore, frequencies of consumption have commonly been used to identify dietary patterns,${ }^{56}$ which are recognized to be relevant not only for assessing the association between total 
299 diet and obesity but also because they can be translated into guidelines for the public. ${ }^{57}$ Finally, 300 although all levels of SEP were represented in this study, the sample is generally well educated (as 301 is most often the case in cohorts), with $81 \%$ of the mothers reporting $\geq$ high school education. 302 Prevalence of overweight and obesity at 5 years was also lower than in the general population, i.e., $3037.6 \%$ vs. $11.9-13.5 \% .^{58} 59$ The presence of a selection bias is therefore possible and may have 304 implications for generalization of the findings. We can hypothesize that better representation of 305 disadvantaged families, in particular of those with clusters of unhealthy behaviors, would have 306 provided more contrast and better power to show higher effect sizes for the supposed longitudinal 307 effects of EBRBs on later adiposity. This may be especially true for dietary patterns, which are 308 known to be strongly socially patterned from early childhood. ${ }^{18}{ }^{29}$ Remarkably, the current findings 309 suggest both adverse and protective effects even in this rather low-risk sample and thus make the 310 public health arguments even stronger.

312 In conclusion, this study shows longitudinal and gender-differentiated relations between screen time 313 and outdoor play in toddlerhood and later adiposity, while less conclusive findings were found for 314 the relation between dietary patterns and subsequent fat development. These results provide 315 additional evidence that early childhood - by age 2 - should be targeted as a critical time for promoting healthy energy balance-related behaviors. 
Acknowledgements: We are extremely grateful to all the families who took part in this study, the midwives and psychologists who recruited and followed them, and the whole EDEN team, including research scientists, engineers, technicians and managers and especially Josiane Sahuquillo and Edith Lesieux for their commitment and their role in the success of the study. We also acknowledge the commitment of the members of the EDEN Mother-Child Cohort Study Group: I. Annesi-Maesano, J.Y. Bernard, J. Botton, M.A. Charles, P. Dargent-Molina, B. de Lauzon-Guillain, P. Ducimetière, M. de Agostini, B. Foliguet, A. Forhan, X. Fritel, A. Germa, V. Goua, R. Hankard, B. Heude, M. Kaminski, B. Larroque†, N. Lelong, J. Lepeule, G. Magnin, L. Marchand, C. Nabet, F Pierre, R. Slama, M.J. Saurel-Cubizolles, M. Schweitzer, O. Thiebaugeorges. We thank Jo Ann Cahn for her help in preparing the manuscript.

Contributors: CSG, PDM and SL conceived and designed the work, with advice from BH and MAC. CSG analyzed the data with advice from BH, JB, PDM and SL. CSG, PDM and SL drafted and revised the manuscript. All authors interpreted the data and criticized the manuscript for important intellectual content. MAC and BH designed and led the EDEN mother-child cohort. AF is responsible for the EDEN data management. JB and SC have fitted weight and height growth trajectories using the Jenss-Bayley nonlinear model and provided the relevant data. All authors have read and approved the final version of the manuscript. This article is the work of the authors. SL serves as guarantor for the contents of this article. All authors had full access to all of the data (including statistical reports and tables) in the study and take the responsibility for the integrity of the data and the accuracy of the data analysis. All researchers are independent of the funding bodies. All members in the EDEN mother-child cohort study group designed the study and revised the draft manuscript.

\section{Supplementary information is available at the International Journal Obesity's website}




\section{REFERENCES}

1. Lobstein T, Baur L, Uauy R. Obesity in children and young people: a crisis in public health. Obes Rev 2004;5 Suppl 1:4-104.

2. de Onis M, Blossner M, Borghi E. Global prevalence and trends of overweight and obesity among preschool children. Am J Clin Nutr 2010;92:1257-1264.

3. Hill JO, Wyatt HR, Reed GW, Peters JC. Obesity and the environment: where do we go from here? Science 2003;299:853-855.

4. Reilly JJ. Physical activity, sedentary behaviour and energy balance in the preschool child: opportunities for early obesity prevention. Proc Nutr Soc 2008;67:317-325.

5. Barnett LM, van Beurden E, Morgan PJ, Brooks LO, Beard JR. Childhood motor skill proficiency as a predictor of adolescent physical activity. J Adolesc Health 2009;44:252-259.

6. Birch LL. Development of food preferences. Аnпи Rev Nutr 1999;19:41-62.

7. Schwartz C, Scholtens PA, Lalanne A, Weenen H, Nicklaus S. Development of healthy eating habits early in life. Review of recent evidence and selected guidelines. Appetite 2011;57:796-807.

8. de Lauzon-Guillain B, Jones L, Oliveira A, Moschonis G, Betoko A, Lopes C, et al. The influence of early feeding practices on fruit and vegetable intake among preschool children in 4 European birth cohorts. Am J Clin Nutr 2013;98:804-812.

9. Mikkila V, Rasanen L, Raitakari OT, Pietinen P, Viikari J. Consistent dietary patterns identified from childhood to adulthood: the cardiovascular risk in Young Finns Study. Br J Nutr 2005;93:923-931.

10. Northstone K, Emmett PM. Are dietary patterns stable throughout early and mid-childhood? A birth cohort study. Br J Nutr 2008;100:1069-1076.

11. Jones RA, Hinkley T, Okely AD, Salmon J. Tracking physical activity and sedentary behavior in childhood: a systematic review. Am J Prev Med 2013;44:651-658.

12. Lioret S, Betoko A, Forhan A, Charles MA, Heude B, de Lauzon-Guillain B. Dietary patterns track from infancy to preschool age: cross-sectional and longitudinal perspectives. $J$ Nutr 2015;145:775-782.

13. Okubo H, Crozier SR, Harvey NC, Godfrey KM, Inskip HM, Cooper C, et al. Diet quality across early childhood and adiposity at 6 years: the Southampton Women's Survey. Int J Obes (Lond) 2015;39:1456-1462.

14. te Velde SJ, van Nassau F, Uijtdewilligen L, van Stralen MM, Cardon G, De Craemer M, et al. Energy balance-related behaviours associated with overweight and obesity in preschool children: a systematic review of prospective studies. Obes Rev 2012;13 Suppl 1:56-74.

15. Jago R, Baranowski T, Baranowski JC, Thompson D, Greaves KA. BMI from 3-6 y of age is predicted by TV viewing and physical activity, not diet. Int J Obes (Lond) 2005;29:557-564.

16. Pagani LS, Fitzpatrick C, Barnett TA, Dubow E. Prospective associations between early childhood television exposure and academic, psychosocial, and physical well-being by middle childhood. Arch Pediatr Adolesc Med 2010;164:425-431. 
17. Downing KL, Hnatiuk J, Hesketh KD. Prevalence of sedentary behavior in children under 2years: A systematic review. Prev Med 2015;78:105-114.

18. Smithers LG, Golley RK, Brazionis L, Lynch JW. Characterizing whole diets of young children from developed countries and the association between diet and health: a systematic review. Nutr Rev 2011;69:449-467.

19. Mast M, Kortzinger I, Konig E, Muller MJ. Gender differences in fat mass of 5-7-year old children. Int J Obes Relat Metab Disord 1998;22:878-884.

20. Timmons BW, Naylor PJ, Pfeiffer KA. Physical activity for preschool children-how much and how? Can J Public Health 2007;98 Suppl 2:S122-134.

21. Hinkley T, Crawford D, Salmon J, Okely AD, Hesketh K. Preschool children and physical activity: a review of correlates. Am J Prev Med 2008;34:435-441.

22. Heude B, Forhan A, Slama R, Douhaud L, Bedel S, Saurel-Cubizolles MJ, et al. Cohort Profile: The EDEN mother-child cohort on the prenatal and early postnatal determinants of child health and development. Int J Epidemiol 2015 Aug 17. pii: dyv151. [Epub ahead of print].

23. Houtkooper LB, Lohman TG, Going SB, Hall MC. Validity of bioelectric impedance for body composition assessment in children. J Appl Physiol (1985) 1989;66:814-821.

24. Slaughter MH, Lohman TG, Boileau RA, Horswill CA, Stillman RJ, Van Loan MD, et al. Skinfold equations for estimation of body fatness in children and youth. Hum Biol 1988;60:709-723.

25. Goran MI, Driscoll P, Johnson R, Nagy TR, Hunter G. Cross-calibration of body-composition techniques against dual-energy X-ray absorptiometry in young children. Am J Clin Nutr 1996;63:299-305.

26. De Craemer M, Lateva M, Iotova V, De Decker E, Verloigne M, De Bourdeaudhuij I, et al. Differences in energy balance-related behaviours in European preschool children: the ToyBox-study. PLoS One 2015;10:e0118303.

27. Carson V, Spence JC. Seasonal variation in physical activity among children and adolescents: a review. Pediatr Exerc Sci 2010;22:81-92.

28. Botton J, Scherdel P, Regnault N, Heude B, Charles MA. Postnatal weight and height growth modeling and prediction of body mass index as a function of time for the study of growth determinants. Ann Nutr Metab 2014;65:156-166.

29. Camara S, de Lauzon-Guillain B, Heude B, Charles MA, Botton J, Plancoulaine S, et al.

Multidimensionality of the relationship between social status and dietary patterns in early childhood: longitudinal results from the French EDEN mother-child cohort. Int J Behav Nutr Phys Act 2015;12:122.

30. LeBlanc AG, Spence JC, Carson V, Connor Gorber S, Dillman C, Janssen I, et al. Systematic review of sedentary behaviour and health indicators in the early years (aged 0-4 years). Appl Physiol Nutr Metab 2012;37:753-772.

31. Klesges RC, Shelton ML, Klesges LM. Effects of television on metabolic rate: potential implications for childhood obesity. Pediatrics 1993;91:281-286. 
32. Bryant MJ, Lucove JC, Evenson KR, Marshall S. Measurement of television viewing in children and adolescents: a systematic review. Obes Rev 2007;8:197-209.

33. Rey-Lopez JP, Vicente-Rodriguez G, Biosca M, Moreno LA. Sedentary behaviour and obesity development in children and adolescents. Nutr Metab Cardiovasc Dis 2008;18:242-251.

34. Zimmerman FJ, Bell JF. Associations of television content type and obesity in children. Am J Public Health 2010;100:334-340.

35. Lioret S, Touvier M, Lafay L, Volatier JL, Maire B. Dietary and physical activity patterns in French children are related to overweight and socioeconomic status. J Nutr 2008;138:101-107.

36. Gubbels JS, van Assema P, Kremers SP. Physical Activity, Sedentary Behavior, and Dietary Patterns among Children. Curr Nutr Rep 2013;2:105-112.

37. Marinelli M, Sunyer J, Alvarez-Pedrerol M, Iniguez C, Torrent M, Vioque J, et al. Hours of television viewing and sleep duration in children: a multicenter birth cohort study. JAMA Pediatr 2014;168:458-464.

38. Reilly JJ, Armstrong J, Dorosty AR, Emmett PM, Ness A, Rogers I, et al. Early life risk factors for obesity in childhood: cohort study. BMJ 2005;330:1357.

39. Scharf RJ, DeBoer MD. Sleep timing and longitudinal weight gain in 4- and 5-year-old children. Pediatr Obes 2015;10:141-148.

40. Plancoulaine S, Lioret S, Regnault N, Heude B, Charles MA. Gender-specific factors associated with shorter sleep duration at age 3 years. J Sleep Res 2015;24:610-620.

41. Brown A. Media use by children younger than 2 years. Pediatrics 2011;128:1040-1045.

42. Strasburger VC. Children, adolescents, obesity, and the media. Pediatrics 2011;128:201-208.

43. Tremblay MS, Leblanc AG, Carson V, Choquette L, Connor Gorber S, Dillman C, et al. Canadian Sedentary Behaviour Guidelines for the Early Years (aged 0-4 years). Appl Physiol Nutr Metab 2012;37:370-391.

44. Department of Health. Australia’s Physical Activity and Sedentary Behaviour Guidelines. 2009. Available from: http://www.health.gov.au/internet/main/publishing.nsf/Content/health-pubhlthstrateg-phys-act-guidelines\#npa05.

45. Carson V, Kuzik N, Hunter S, Wiebe SA, Spence JC, Friedman A, et al. Systematic review of sedentary behavior and cognitive development in early childhood. Prev Med 2015;78:115-122.

46. Brown WH, Pfeiffer KA, McIver KL, Dowda M, Addy CL, Pate RR. Social and environmental factors associated with preschoolers' nonsedentary physical activity. Child Dev 2009;80:45-58.

47. Burdette HL, Whitaker RC, Daniels SR. Parental report of outdoor playtime as a measure of physical activity in preschool-aged children. Arch Pediatr Adolesc Med 2004;158:353-357.

48. Cleland V, Timperio A, Salmon J, Hume C, Baur LA, Crawford D. Predictors of time spent outdoors among children: 5-year longitudinal findings. J Epidemiol Community Health 2010;64:400-406. 
49. Institute of Medicine of the National Academies. Early Childhood Obesity Prevention Policies. Washington (DC), US: The National Academies Press., 2001.

50. Department of Health and Ageing. Get up and grow: Healthy eating and physical activity for early childhood. Commonwealth of Australia, 2009. Available from: https://www.health.gov.au/internet/main/publishing.nsf/Content/2CDB3A000FE57A4ECA257BF00 01916EC/\$File/HEPA\%20-\%20B5\%20Book\%20-\%20Staff\%20and\%20Carer\%20Book_LR.pdf.

51. Department of Health, Physical Activity, Health Improvement and Protection. Start Active, Stay Active: A report on physical activity for health from home countries' Chief Medical Officers, 2011.

52. Hesketh KD, Hinkley T, Campbell KJ. Children's physical activity and screen time: qualitative comparison of views of parents of infants and preschool children. Int J Behav Nutr Phys Act 2012;9:152.

53. Sallis JF. Age-related decline in physical activity: a synthesis of human and animal studies. Med Sci Sports Exerc 2000;32:1598-1600.

54. Johnson L, Mander AP, Jones LR, Emmett PM, Jebb SA. Energy-dense, low-fiber, high-fat dietary pattern is associated with increased fatness in childhood. Am J Clin Nutr 2008;87:846-854.

55. Noethlings U, Hoffmann K, Bergmann MM, Boeing H. Portion size adds limited information on variance in food intake of participants in the EPIC-Potsdam study. $J$ Nutr 2003;133:510-515.

56. Newby PK, Tucker KL. Empirically derived eating patterns using factor or cluster analysis: a review. Nutr Rev 2004;62:177-203.

57. Ambrosini GL. Childhood dietary patterns and later obesity: a review of the evidence. Proc Nutr Soc 2014;73:137-146.

58. Lioret S, Touvier M, Dubuisson C, Dufour A, Calamassi-Tran G, Lafay L, et al. Trends in child overweight rates and energy intake in France from 1999 to 2007: relationships with socioeconomic status. Obesity (Silver Spring) 2009;17:1092-1100.

59. Chardon O, Guignon N, de Saint Pol T. La santé des élèves de grande section de maternelle en 2013: des inégalités sociales dès le plus jeune âge. Etudes et résultats. Direction de la recherche, des études, de l'évaluation et des statistiques 2015;0920.

60. Cole TJ, Bellizzi MC, Flegal KM, Dietz WH. Establishing a standard definition for child overweight and obesity worldwide: international survey. Br Med J 2000;320:1240-1243. 


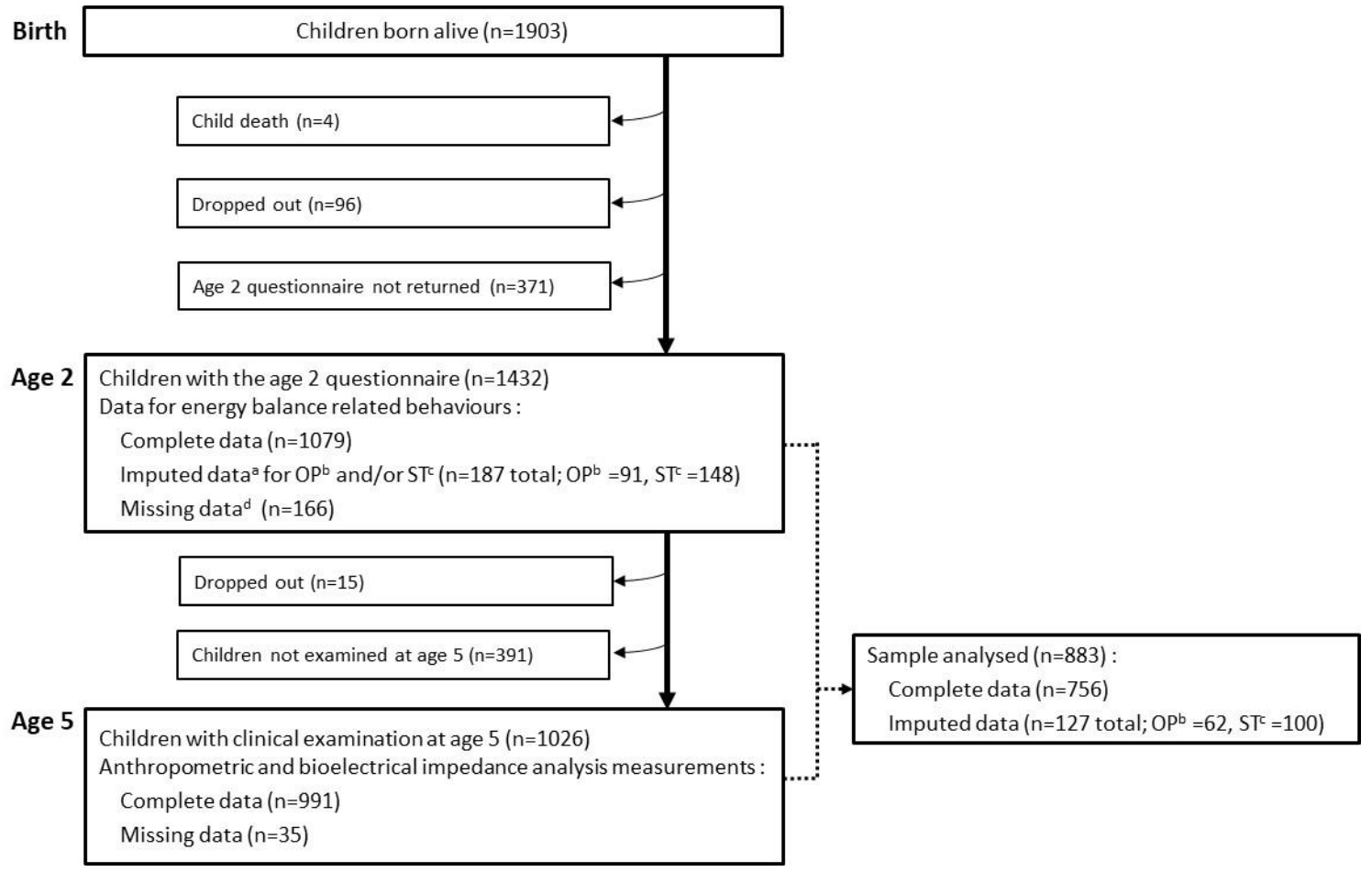

Figure 1: Flow diagram for selection of children

${ }^{a}$ Non-reponses to 1 or 2 questions regarding outdoor play and/or screen time were imputed (see methods);

${ }^{b}$ Outdoor play time; ${ }^{c}$ Screen time; ${ }^{d}$ Completely missing for one or more energy balance-related behaviors. 
Table 1. Children's characteristics, by gender (values are percentages (numbers) unless stated otherwise). The EDEN mother-child cohort.

\begin{tabular}{|c|c|c|c|}
\hline & Boys $(n=473)$ & Girls $(n=410)$ & $\boldsymbol{P}$ \\
\hline \multicolumn{4}{|l|}{ Variables at inclusion or birth } \\
\hline \multicolumn{4}{|l|}{ Maternal education } \\
\hline Did not complete high school & $20.1(95)$ & $18.5(76)$ & 0.84 \\
\hline High school diploma & $17.8(84)$ & $17.1(70)$ & \\
\hline 2-year university degree & $26.0(123)$ & $25.4(104)$ & \\
\hline$\geq 3$-year university degree & $36.1(171)$ & $39.0(160)$ & \\
\hline \multicolumn{4}{|l|}{ Household income, $€ /$ month } \\
\hline$\leq 1500$ & $11.6(55)$ & $9.7(40)$ & 0.51 \\
\hline 1501 to 2300 & $28.8(136)$ & $27.1(111)$ & \\
\hline 2301 to 3000 & $32.4(153)$ & $31.0(127)$ & \\
\hline 3001 to 3800 & $15.4(73)$ & $19.5(80)$ & \\
\hline$>3800$ & $11.8(56)$ & $12.7(52)$ & \\
\hline \multicolumn{4}{|l|}{ Centre } \\
\hline Nancy & $56.0(265)$ & $49.8(204)$ & 0.06 \\
\hline Poitiers & $44.0(208)$ & $50.2(206)$ & \\
\hline Maternal age at delivery $(\mathrm{y})$, mean(SD) & $30.2(4.7)$ & $30.1(4.8)$ & 0.77 \\
\hline Birth weight (g), mean (SD) & $3357(526)$ & $3218(482)$ & $<0.001$ \\
\hline \multicolumn{4}{|l|}{ Children's characteristics at age 2 years } \\
\hline \multicolumn{4}{|l|}{ Screen time, $\min /$ day } \\
\hline$\leq 15$ & $33.8(160)$ & $34.6(142)$ & 0.43 \\
\hline$>15$ to $<60$ & $31.3(148)$ & $34.4(141)$ & \\
\hline$\geq 60$ & $34.9(165)$ & $31.0(127)$ & \\
\hline \multicolumn{4}{|l|}{ Outdoor play time ${ }^{a}$} \\
\hline Low (Tertile 1) & $28.5(135)$ & $38.3(157)$ & 0.003 \\
\hline Medium (Tertile 2) & $34.0(161)$ & $33.2(136)$ & \\
\hline High (Tertile 3) & $37.4(177)$ & $28.5(117)$ & \\
\hline "Processed, fast food" dietary pattern scores, mean (SD) & $-0.03(0.96)$ & $-0.04(0.96)$ & 0.80 \\
\hline "Guidelines" dietary pattern scores, mean (SD) & $-0.02(0.93)$ & $0.10(0.97)$ & 0.080 \\
\hline BMI $\left(\mathrm{kg} / \mathrm{m}^{2}\right)^{b}$, mean $(\mathrm{SD})$ & $17.3(1.9)$ & $17.5(2)$ & 0.048 \\
\hline \multicolumn{4}{|l|}{ Children's characteristics at age 5 years } \\
\hline $\mathrm{BMI}\left(\mathrm{kg} / \mathrm{m}^{2}\right)$ mean $(\mathrm{SD})$ & $15.4(1.3)$ & $15.4(1.4)$ & 0.74 \\
\hline Prevalence of overweight (including obesity) ${ }^{c}$ & $5.7(27)$ & $9.8(40)$ & 0.024 \\
\hline Percentage of body fat ${ }^{d}$, mean (SD) & $12.6(2.9)$ & $16.7(3.2)$ & $<0.001$ \\
\hline \multicolumn{4}{|c|}{ 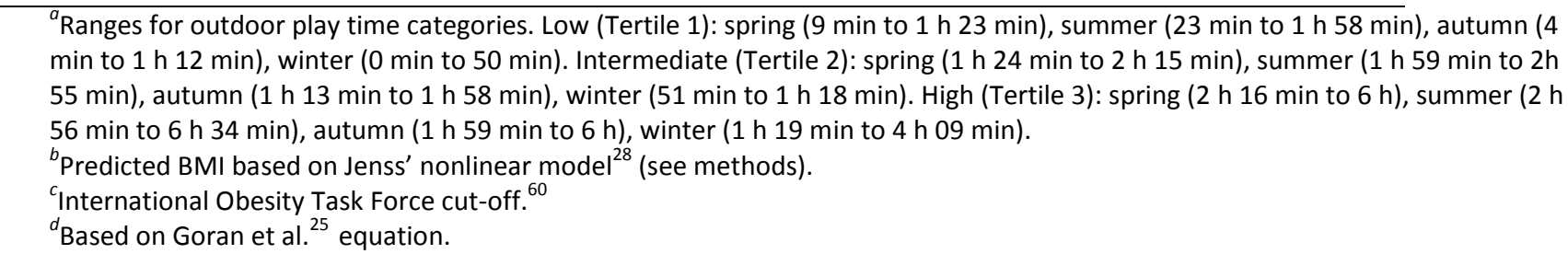 } \\
\hline
\end{tabular}


Table 2. Associations between dietary patterns scores ${ }^{a}$ and both outdoor play and screen times (values are linear regression coefficients $(95 \% \mathrm{CI}))^{b}$. The EDEN mother-child cohort

\begin{tabular}{|c|c|c|c|c|}
\hline \multirow[b]{3}{*}{ Outdoor play time ${ }^{c}$} & \multicolumn{2}{|c|}{ Boys $(n=473)$} & \multicolumn{2}{|c|}{ Girls $(n=410)$} \\
\hline & \multirow[t]{2}{*}{$\begin{array}{l}\text { "Processed, fast } \\
\text { food" dietary } \\
\text { pattern scores }\end{array}$} & \multirow[t]{2}{*}{$\begin{array}{c}\text { "Guidelines" } \\
\text { dietary pattern } \\
\text { scores } \\
\end{array}$} & \multirow[t]{2}{*}{$\begin{array}{l}\text { "Processed, fast } \\
\text { food" dietary } \\
\text { pattern scores }\end{array}$} & \multirow[t]{2}{*}{$\begin{array}{c}\text { "Guidelines" } \\
\text { dietary pattern } \\
\text { scores }\end{array}$} \\
\hline & & & & \\
\hline Low (Tertile 1) & ref & ref & ref & ref \\
\hline Intermediate (Tertile 2) & $\begin{array}{c}0.10 \\
(-0.11,0.31)\end{array}$ & $\begin{array}{c}0.08 \\
(-0.13,0.29)\end{array}$ & $\begin{array}{c}-0.04 \\
(-0.25,0.18)\end{array}$ & $\begin{array}{c}-0.08 \\
(-0.30,0.14)\end{array}$ \\
\hline High (Tertile 3) & $\begin{array}{c}0.22 \\
(0.01,0.43)\end{array}$ & $\begin{array}{c}-0.04 \\
(-0.24,0.17)\end{array}$ & $\begin{array}{c}0.24 \\
(0.00,0.47)\end{array}$ & $\begin{array}{c}0.41 \\
(0.17,0.64)\end{array}$ \\
\hline$P$ & 0.12 & 0.52 & 0.052 & 0.0002 \\
\hline \multicolumn{5}{|l|}{ Screen time (min/day) } \\
\hline$\leq 15$ & ref & ref & ref & ref \\
\hline$>15$ to $<60$ & $\begin{array}{c}0.03 \\
(-0.18,0.23)\end{array}$ & $\begin{array}{c}0.05 \\
(-0.16,0.26)\end{array}$ & $\begin{array}{c}0.23 \\
(0.01,0.44)\end{array}$ & $\begin{array}{c}0.07 \\
(-0.16,0.30)\end{array}$ \\
\hline$\geq 60$ & $\begin{array}{c}0.38 \\
(0.18,0.58)\end{array}$ & $\begin{array}{c}0.06 \\
(-0.15,0.26)\end{array}$ & $\begin{array}{c}0.17 \\
(-0.07,0.40)\end{array}$ & $\begin{array}{c}-0.05 \\
(-0.29,0.19)\end{array}$ \\
\hline$P$ & 0.0002 & 0.83 & 0.12 & 0.60 \\
\hline \multicolumn{5}{|c|}{ 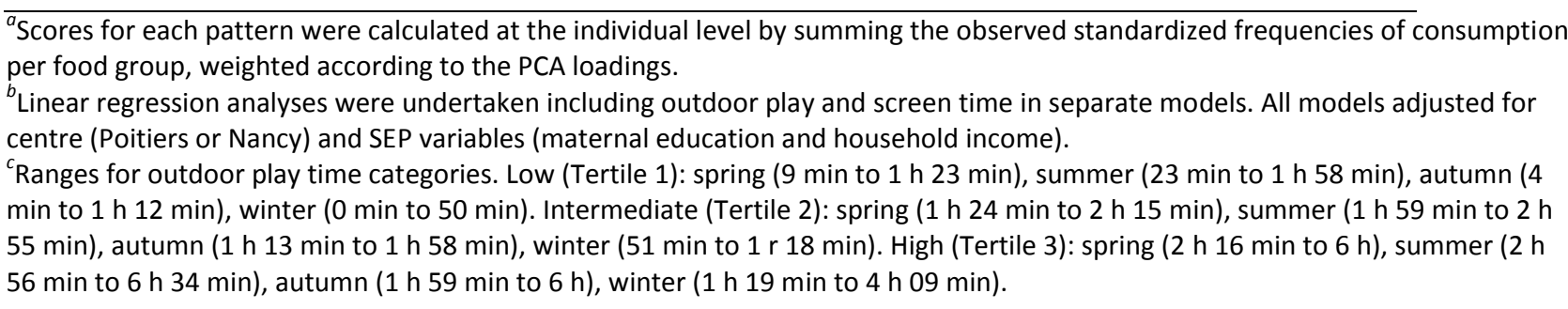 } \\
\hline
\end{tabular}


Table 3. Associations between EBRBs ${ }^{a}$ at age 2 and adiposity at age 5 (values are linear regression coefficients (95\% CI)). The EDEN motherchild cohort.

\begin{tabular}{|c|c|c|c|c|c|c|c|c|}
\hline & \multicolumn{4}{|c|}{ Boys $(n=473)$} & \multicolumn{4}{|c|}{ Girls $(n=410)$} \\
\hline & \multicolumn{2}{|c|}{$\% \mathrm{BF}^{b}$} & \multicolumn{2}{|c|}{ BMI } & \multicolumn{2}{|c|}{$\% \mathrm{BF}^{b}$} & \multicolumn{2}{|c|}{ BMI } \\
\hline & $\begin{array}{l}\text { Separate } \\
\text { models }^{c}\end{array}$ & $\begin{array}{c}\text { Fully-adjusted } \\
\text { model }^{d}\end{array}$ & $\begin{array}{l}\text { Separate } \\
\text { models }\end{array}$ & $\begin{array}{c}\text { Fully-adjusted } \\
\text { model }^{d}\end{array}$ & $\begin{array}{l}\text { Separate } \\
\text { models }^{c}\end{array}$ & $\begin{array}{c}\text { Fully-adjusted } \\
\text { model }^{d}\end{array}$ & $\begin{array}{l}\text { Separate } \\
\text { models }^{c}\end{array}$ & $\begin{array}{c}\text { Fully-adjusted } \\
\text { model }^{d}\end{array}$ \\
\hline \multicolumn{9}{|l|}{ Outdoor play time $(\mathrm{min} / \mathrm{d})^{e}$} \\
\hline Low (Tertile 1) & ref & ref & ref & ref & ref & ref & ref & ref \\
\hline Intermediate (Tertile 2) & $\begin{array}{c}-0.31 \\
(-0.82,0.19)\end{array}$ & $\begin{array}{c}-0.33 \\
(-0.84,0.18)\end{array}$ & $\begin{array}{c}0.02 \\
(-0.04,0.31)\end{array}$ & $\begin{array}{c}0.02 \\
(-0.16,0.20)\end{array}$ & $\begin{array}{c}0.27 \\
(-0.31,0.85)\end{array}$ & $\begin{array}{c}0.26 \\
(-0.34,0.85)\end{array}$ & $\begin{array}{c}0.05 \\
(-0.15,0.24)\end{array}$ & $\begin{array}{c}0.06 \\
(-0.14,0.27)\end{array}$ \\
\hline High (Tertile 3) & $\begin{array}{c}-0.11 \\
(-0.61,0.39)\end{array}$ & $\begin{array}{c}-0.14 \\
(-0.64,0.37)\end{array}$ & $\begin{array}{c}0.13 \\
(-0.16,0.19)\end{array}$ & $\begin{array}{c}0.14 \\
(-0.03,0.32)\end{array}$ & $\begin{array}{c}-0.89 \\
(-1.50,-0.28)\end{array}$ & $\begin{array}{c}-0.93 \\
(-1.58,-0.28)\end{array}$ & $\begin{array}{c}-0.09 \\
(-0.30,0.11)\end{array}$ & $\begin{array}{c}-0.06 \\
(-0.28,0.16)\end{array}$ \\
\hline$P$ & 0.46 & 0.43 & 0.25 & 0.21 & 0.001 & 0.002 & 0.43 & 0.55 \\
\hline \multicolumn{9}{|l|}{ Screen time $(\mathrm{min} / \mathrm{d})$} \\
\hline$\leq 15$ & ref & ref & ref & ref & ref & ref & ref & ref \\
\hline$>15$ to $<60$ & $\begin{array}{c}0.25 \\
(-0.25,0.74)\end{array}$ & $\begin{array}{c}0.25 \\
(-0.25,0.74)\end{array}$ & $\begin{array}{c}0.08 \\
(-0.10,0.25)\end{array}$ & $\begin{array}{c}0.08 \\
(-0.09,0.26)\end{array}$ & $\begin{array}{c}0.33 \\
(-0.27,0.93)\end{array}$ & $\begin{array}{c}0.26 \\
(-0.34,0.86)\end{array}$ & $\begin{array}{c}0.11 \\
(-0.09,0.31)\end{array}$ & $\begin{array}{c}0.08 \\
(-0.12,0.29)\end{array}$ \\
\hline$\geq 60$ & $\begin{array}{c}0.48 \\
(0.00,0.96)\end{array}$ & $\begin{array}{c}0.51 \\
(0.02,1.01)\end{array}$ & $\begin{array}{c}0.002 \\
(-0.17,0.17)\end{array}$ & $\begin{array}{c}0.04 \\
(-0.14,0.21)\end{array}$ & $\begin{array}{c}0.14 \\
(-0.48,0.76)\end{array}$ & $\begin{array}{c}0.06 \\
(-0.58,0.70)\end{array}$ & $\begin{array}{c}0.07 \\
(-0.140 .28)\end{array}$ & $\begin{array}{c}0.04 \\
(-0.18,0.26)\end{array}$ \\
\hline$P$ & $0.053^{f}$ & $0.045^{f}$ & 0.62 & 0.65 & 0.55 & 0.68 & 0.56 & 0.72 \\
\hline \multicolumn{9}{|l|}{ Dietary patterns (scores) } \\
\hline "Processed, fast-food" & $\begin{array}{c}0.04 \\
(-0.17,0.25)\end{array}$ & $\begin{array}{c}0.02 \\
(-0.20,0.25)\end{array}$ & $\begin{array}{c}-0.04 \\
(-0.11,0.04)\end{array}$ & $\begin{array}{c}-0.04 \\
(-0.11,0.04)\end{array}$ & $\begin{array}{c}0.15 \\
(-0.10,0.41)\end{array}$ & $\begin{array}{c}0.19 \\
(-0.08,0.46)\end{array}$ & $\begin{array}{c}0.07 \\
(-0.02,0.16)\end{array}$ & $\begin{array}{c}0.08 \\
(-0.01,0.17)\end{array}$ \\
\hline$P$ & 0.690 & 0.829 & 0.324 & 0.364 & 0.244 & 0.176 & 0.106 & 0.099 \\
\hline "Guidelines" & $\begin{array}{c}-0.02 \\
(-0.23,0.20)\end{array}$ & $\begin{array}{c}0.00 \\
(-0.22,0.22)\end{array}$ & $\begin{array}{c}0.01 \\
(-0.08,0.07)\end{array}$ & $\begin{array}{c}-0.01 \\
(-0.09,0.07)\end{array}$ & $\begin{array}{c}-0.31 \\
(-0.57,-0.06)\end{array}$ & $\begin{array}{c}-0.21 \\
(-0.47,0.06)\end{array}$ & $\begin{array}{c}-0.08 \\
(-0.17,0.01)\end{array}$ & $\begin{array}{c}-0.07 \\
(-0.16,0.02)\end{array}$ \\
\hline$P$ & 0.87 & 0.97 & 0.90 & 0.81 & 0.017 & 0.12 & 0.067 & 0.12 \\
\hline
\end{tabular}

${ }^{a}$ Energy balance-related behaviors.

${ }^{b}$ Body fat percentage measured and calculated based on Goran's equation. ${ }^{25}$

${ }^{c}$ Screen time, outdoor play and dietary patterns were included in three separate models, which adjusted for center (Poitiers or Nancy), baseline BMI and exact age at the age 5 clinical examination.

${ }^{d}$ The three EBRBs were included simultaneously along with the SEP variables (maternal education and household income). All models adjusted for center (Poitiers or Nancy), baseline BMI and exact age at the age 5 clinical examination.

${ }^{e}$ Ranges for outdoor play time categories. Low (Tertile 1 ): spring ( $9 \mathrm{~min}$ to $1 \mathrm{~h} 23 \mathrm{~min}$ ), summer ( $23 \mathrm{~min}$ to $1 \mathrm{~h} 58 \mathrm{~min}$ ), autumn (4 min to $1 \mathrm{~h} 12 \mathrm{~min}$ ), winter (0 min to $50 \mathrm{~min}$ ). Intermediate (Tertile 2): spring ( $1 \mathrm{~h} 24 \mathrm{~min}$ to $2 \mathrm{~h} 15 \mathrm{~min}$ ), summer ( $1 \mathrm{~h} 59 \mathrm{~min}$ to $2 \mathrm{~h} 55 \mathrm{~min}$ ), autumn ( $1 \mathrm{~h} 13 \mathrm{~min}$ to $1 \mathrm{~h} 58 \mathrm{~min}$ ), winter (51 min to $1 \mathrm{r} 18 \mathrm{~min}$ ). High (Tertile 3 ): spring ( $2 \mathrm{~h} 16 \mathrm{~min}$ to $6 \mathrm{~h}$ ), summer ( $2 \mathrm{~h} 56 \mathrm{~min}$ to $6 \mathrm{~h} 34 \mathrm{~min}$ ), autumn ( $1 \mathrm{~h} 59 \mathrm{~min}$ to $6 \mathrm{~h}$ ), winter ( $1 \mathrm{~h} 19 \mathrm{~min}$ to $4 \mathrm{~h} 09 \mathrm{~min}$ ).

${ }^{f} \mathrm{P}$ trend assessed using the median value of each category of the variable (after testing the linearity of the association using a F-test, $\mathrm{P}$-values $>0.95$ ). 
Supplementary Table 1. Associations between $\mathrm{EBRBs}^{a}$ at age 2 and adiposity at age 5 (values are linear regression coefficients (95\% CI)). The EDEN mother-child cohort.

\begin{tabular}{|c|c|c|c|c|c|c|c|c|}
\hline & \multicolumn{4}{|c|}{ Boys $(n=473)$} & \multicolumn{4}{|c|}{ Girls $(n=410)$} \\
\hline & \multicolumn{2}{|c|}{$\% \mathrm{BF}^{b}$ from Slaughter } & \multicolumn{2}{|c|}{$\% \mathrm{BF}^{b}$ from Houtkooper } & \multicolumn{2}{|c|}{${ } \mathbf{B F}^{b}$ from Slaughter } & \multicolumn{2}{|c|}{ \%BF ${ }^{b}$ from Houtkooper } \\
\hline & $\begin{array}{l}\text { Separate } \\
\text { models }^{c}\end{array}$ & $\begin{array}{l}\text { Fully-adjusted } \\
\text { model }^{d}\end{array}$ & $\begin{array}{l}\text { Separate } \\
\text { models }^{c}\end{array}$ & $\begin{array}{l}\text { Fully-adjusted } \\
\text { model }^{d}\end{array}$ & $\begin{array}{l}\text { Separate } \\
\text { models }^{c}\end{array}$ & $\begin{array}{l}\text { Fully-adjusted } \\
\text { model }^{d}\end{array}$ & $\begin{array}{l}\text { Separate } \\
\text { models }^{c}\end{array}$ & $\begin{array}{l}\text { Fully-adjusted } \\
\text { model }^{d}\end{array}$ \\
\hline \multicolumn{9}{|l|}{ Outdoor play time $(\mathrm{min} / \mathrm{d})^{e}$} \\
\hline Low (Tertile 1) & ref & ref & ref & ref & ref & ref & ref & ref \\
\hline Intermediate (Tertile 2) & $\begin{array}{c}-0.28 \\
(-0.81,0.24)\end{array}$ & $\begin{array}{c}-0.34 \\
(-0.61,0.44)\end{array}$ & $\begin{array}{c}-0.48 \\
(-1.37,0.42)\end{array}$ & $\begin{array}{c}-0.47 \\
(-1.38,0.43)\end{array}$ & $\begin{array}{c}0.35 \\
(-0.23,0.94)\end{array}$ & $\begin{array}{c}0.34 \\
(-0.26,0.93)\end{array}$ & $\begin{array}{c}0.04 \\
(-0.89,0.97)\end{array}$ & $\begin{array}{c}0.003 \\
(-0.94,0.95)\end{array}$ \\
\hline High (Tertile 3) & $\begin{array}{c}-0.03 \\
(-0.55,0.49)\end{array}$ & $\begin{array}{c}-0.08 \\
(-0.87,0.20)\end{array}$ & $\begin{array}{c}-0.45 \\
(-1.32,0.43)\end{array}$ & $\begin{array}{c}-0.46 \\
(-1.35,0.43)\end{array}$ & $\begin{array}{c}-0.61 \\
(-1.22,-0.01)\end{array}$ & $\begin{array}{c}-0.72 \\
(-1.37,-0.06)\end{array}$ & $\begin{array}{c}-1.68 \\
(-2.66,-0.71)\end{array}$ & $\begin{array}{c}-1.63 \\
(-2.66,-0.59)\end{array}$ \\
\hline$P$ & 0.49 & 0.42 & 0.51 & 0.51 & 0.010 & 0.007 & 0.001 & 0.003 \\
\hline \multicolumn{9}{|l|}{ Screen time $(\mathrm{min} / \mathrm{d})$} \\
\hline$\leq 15$ & ref & ref & ref & ref & ref & ref & ref & ref \\
\hline$>15$ to $<60$ & $\begin{array}{c}0.24 \\
(-0.27,0.76)\end{array}$ & $\begin{array}{c}0.25 \\
(-0.27,0.77)\end{array}$ & $\begin{array}{c}0.33 \\
(-0.55,1.20)\end{array}$ & $\begin{array}{c}0.32 \\
(-0.56,1.19)\end{array}$ & $\begin{array}{c}-0.03 \\
(-0.62,0.56)\end{array}$ & $\begin{array}{c}-0.13 \\
(-0.73,0.47)\end{array}$ & $\begin{array}{c}1.14 \\
(0.19,2.09)\end{array}$ & $\begin{array}{c}1.15 \\
(0.19,2.10)\end{array}$ \\
\hline$\geq 60$ & $\begin{array}{c}0.50 \\
(0.00,1.00)\end{array}$ & $\begin{array}{c}0.51 \\
(-0.01,1.02)\end{array}$ & $\begin{array}{c}0.74 \\
(-0.11,1.58)\end{array}$ & $\begin{array}{c}0.77 \\
(-0.10,1.65)\end{array}$ & $\begin{array}{c}-0.09 \\
(-0.70,0.52)\end{array}$ & $\begin{array}{c}-0.21 \\
(-0.84,0.43)\end{array}$ & $\begin{array}{c}0.74 \\
(-0.24,1.72)\end{array}$ & $\begin{array}{c}0.80 \\
(-0.21,1.81)\end{array}$ \\
\hline$P$ & $0.052^{f}$ & $0.045^{f}$ & $0.089^{f}$ & $0.083^{f}$ & 0.96 & 0.81 & 0.058 & 0.057 \\
\hline \multicolumn{9}{|l|}{ Dietary patterns (scores) } \\
\hline "Processed, fast-food" & $\begin{array}{c}0.06 \\
(-0.15,0.28)\end{array}$ & $\begin{array}{c}0.02 \\
(-0.21,0.25)\end{array}$ & $\begin{array}{c}0.06 \\
(-0.31,0.43)\end{array}$ & $\begin{array}{c}0.06 \\
(-0.33,0.45)\end{array}$ & $\begin{array}{c}0.15 \\
(-0.11,0.41)\end{array}$ & $\begin{array}{c}0.18 \\
(-0.09,0.45)\end{array}$ & $\begin{array}{c}0.12 \\
(-0.29,0.53)\end{array}$ & $\begin{array}{c}0.17 \\
(-0.26,0.60)\end{array}$ \\
\hline$P$ & 0.570 & 0.873 & 0.766 & 0.764 & 0.250 & 0.188 & 0.575 & 0.428 \\
\hline "Guidelines" & $\begin{array}{c}-0.02 \\
(-0.25,0.20)\end{array}$ & $\begin{array}{c}0.01 \\
(-0.22,0.24)\end{array}$ & $\begin{array}{c}-0.12 \\
(-0.50,0.26)\end{array}$ & $\begin{array}{c}-0.11 \\
(-0.50,0.27)\end{array}$ & $\begin{array}{c}-0.23 \\
(-0.48,0.03)\end{array}$ & $\begin{array}{c}-0.14 \\
(-0.40,0.13)\end{array}$ & $\begin{array}{c}-0.50 \\
(-0.91,-0.10)\end{array}$ & $\begin{array}{c}-0.36 \\
(-0.78,0.06)\end{array}$ \\
\hline$P$ & 0.83 & 0.93 & 0.55 & 0.56 & 0.080 & 0.31 & 0.016 & 0.092 \\
\hline \multicolumn{9}{|c|}{ 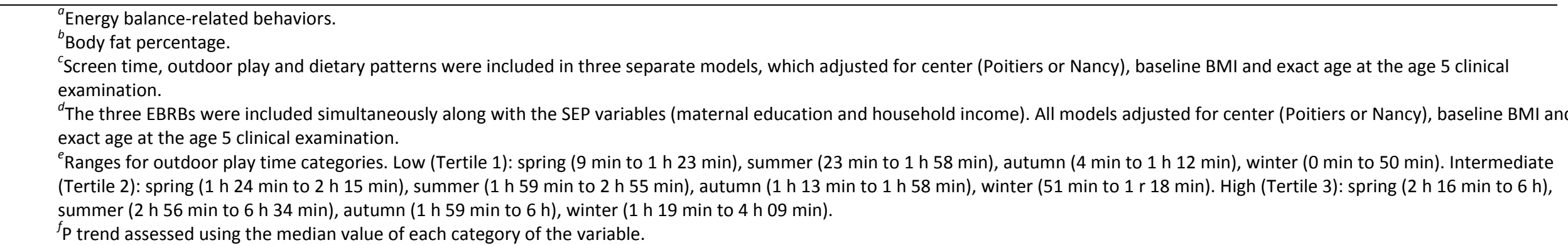 } \\
\hline
\end{tabular}


Supplementary Table 2. Associations between $\mathrm{EBRBs}^{a}$ at age 2 and adiposity at age 5 in the sample with complete case data (values are linear regression coefficients $(95 \% \mathrm{CI})$ ). The EDEN motherchild cohort.

\begin{tabular}{|c|c|c|c|c|}
\hline & \multirow{2}{*}{\multicolumn{2}{|c|}{$\begin{array}{c}\text { Boys }(\mathbf{n}=411) \\
\% \mathrm{BF}^{b}\end{array}$}} & \multirow{2}{*}{\multicolumn{2}{|c|}{$\begin{array}{c}\text { Girls }(\mathbf{n}=345) \\
\% \mathrm{BF}^{b}\end{array}$}} \\
\hline & & & & \\
\hline & $\begin{array}{l}\text { Separate } \\
\text { models }^{c}\end{array}$ & $\begin{array}{c}\text { Fully-adjusted } \\
\text { model }^{d}\end{array}$ & $\begin{array}{l}\text { Separate } \\
\text { models }^{c}\end{array}$ & $\begin{array}{c}\text { Fully-adjusted } \\
\text { model }^{d}\end{array}$ \\
\hline \multicolumn{5}{|l|}{ Outdoor play time $(\mathrm{min} / \mathrm{d})^{e}$} \\
\hline Low (Tertile 1) & ref & ref & ref & ref \\
\hline Intermediate (Tertile 2) & $\begin{array}{c}-0.25 \\
(-0.79,0.30)\end{array}$ & $\begin{array}{c}-0.24 \\
(-0.79,0.31)\end{array}$ & $\begin{array}{c}0.29 \\
(-0.36,0.94)\end{array}$ & $\begin{array}{c}0.32 \\
(-0.34,0.98)\end{array}$ \\
\hline High (Tertile 3) & $\begin{array}{c}-0.14 \\
(-0.68,0.40)\end{array}$ & $\begin{array}{c}-0.13 \\
(-0.68,0.42)\end{array}$ & $\begin{array}{c}-1.00 \\
(-1.67,-0.33)\end{array}$ & $\begin{array}{c}-1.05 \\
(-1.77,-0.34)\end{array}$ \\
\hline$P$ & 0.671 & 0.69 & 0.001 & 0.001 \\
\hline \multicolumn{5}{|l|}{ Screen time $(\mathrm{min} / \mathrm{d})$} \\
\hline$\leq 15$ & ref & ref & ref & ref \\
\hline$>15$ to $<60$ & $\begin{array}{c}0.29 \\
(-0.25,0.83)\end{array}$ & $\begin{array}{c}0.29 \\
(-0.25,0.84)\end{array}$ & $\begin{array}{c}0.33 \\
(-0.34,1.01)\end{array}$ & $\begin{array}{c}0.20 \\
(-0.48,0.88)\end{array}$ \\
\hline$\geq 60$ & $\begin{array}{c}0.54 \\
(0.03,1.06)\end{array}$ & $\begin{array}{c}0.60 \\
(0.07,1.13)\end{array}$ & $\begin{array}{c}-0.04 \\
(-0.73,0.66)\end{array}$ & $\begin{array}{c}-0.20 \\
(-0.92,0.52)\end{array}$ \\
\hline$P$ & $0.042^{f}$ & $0.028^{f}$ & 0.49 & 0.52 \\
\hline \multicolumn{5}{|l|}{ Dietary patterns (scores) } \\
\hline "Processed, fast-food" & $\begin{array}{c}-0.0002 \\
(-0.22,0.22)\end{array}$ & $\begin{array}{c}-0.01 \\
(-0.24,0.23)\end{array}$ & $\begin{array}{c}0.11 \\
(-0.18,0.40)\end{array}$ & $\begin{array}{c}0.15 \\
(-0.51,0.08)\end{array}$ \\
\hline$P$ & 0.999 & 0.951 & 0.444 & 0.317 \\
\hline "Guidelines" & $\begin{array}{c}-0.04 \\
(-0.28,0.19)\end{array}$ & $\begin{array}{c}-0.03 \\
(-0.27,0.20)\end{array}$ & $\begin{array}{c}-0.33 \\
(-0.62,-0.05)\end{array}$ & $\begin{array}{c}-0.21 \\
(-1.36,-0.18)\end{array}$ \\
\hline$P$ & 0.72 & 0.79 & 0.023 & 0.16 \\
\hline
\end{tabular}

${ }^{a}$ Energy balance-related behaviors.

${ }^{b}$ Body fat percentage measured and calculated based on Goran's equation. ${ }^{25}$

${ }^{c}$ Screen time, outdoor play and dietary patterns were included in three separate models, which adjusted for center (Poitiers or Nancy), baseline BMI and exact age at the age 5 clinical examination.

${ }^{d}$ The three EBRBs were included simultaneously along with the SEP variables (maternal education and household income). All models adjusted for center (Poitiers or Nancy), baseline BMI and exact age at the age 5 clinical examination.

${ }^{e}$ Ranges for outdoor play time categories. Low (Tertile 1 ): spring (9 min to $1 \mathrm{~h} 23 \mathrm{~min}$ ), summer (23 min to $1 \mathrm{~h} 58 \mathrm{~min}$ ), autumn (4 $\min$ to $1 \mathrm{~h} 12 \mathrm{~min}$ ), winter (0 min to $50 \mathrm{~min}$ ). Intermediate (Tertile 2): spring ( $1 \mathrm{~h} 24 \mathrm{~min}$ to $2 \mathrm{~h} 15 \mathrm{~min}$ ), summer $(1 \mathrm{~h} 59 \mathrm{~min}$ to $2 \mathrm{~h}$ $55 \mathrm{~min}$ ), autumn ( $1 \mathrm{~h} 13 \mathrm{~min}$ to $1 \mathrm{~h} 58 \mathrm{~min}$ ), winter (51 min to $1 \mathrm{r} 18 \mathrm{~min}$ ). High (Tertile 3): spring ( $2 \mathrm{~h} 16 \mathrm{~min}$ to $6 \mathrm{~h}$ ), summer ( $\mathrm{h}$ $56 \mathrm{~min}$ to $6 \mathrm{~h} 34 \mathrm{~min}$ ), autumn ( $1 \mathrm{~h} 59 \mathrm{~min}$ to $6 \mathrm{~h}$ ), winter ( $1 \mathrm{~h} 19 \mathrm{~min}$ to $4 \mathrm{~h} 09 \mathrm{~min}$ ).

${ }^{f} \mathrm{P}$ trend assessed using the median value of each category of the variable. 
